\title{
TEMPORAL VARIATIONS IN THE DEEP ICE-CORE CHEMISTRY RECORD FROM DYE 3, GREENLAND
}

\author{
(Abstract) \\ by \\ C.C. Langway, Jr and $\mathrm{K}$. Goto-Azuma \\ (Department of Geological Sciences, State University of New York at Buffalo, \\ 4240 Ridge Lea Road, Amherst, NY 14226, U.S.A.)
}

\begin{abstract}
Measurements of the chemical constituents in polar-snow deposits translate into chronological records representing a history of atmospheric composition for the periods involved. The $2037 \mathrm{~m}$ deep continuous and undisturbed ice core recovered at Dye 3, Greenland, between 1979 and 1981 contains a temporal record of sequential snow deposits for the past $9 \times 10^{4}$ a B.P. (Dansgaard and others 1985). The upper $90 \mathrm{~m}$ of the deep core were unsuitable for chemistry studies, but stratigraphic continuity with present-day accumulation was obtained by hand-excavating a $5.4 \mathrm{~m}$ deep pit and augering two shallow cores to 138 and $113 \mathrm{~m}$ depths. The pit and shallow cores represent the last two centuries of snow precipitation.
\end{abstract}

To date, over 6000 individual samples of the pit, shallow and deep ice cores have been measured by ion chromatography for $\mathrm{Cl}^{-}, \mathrm{NO}_{3}^{-}$, and $\mathrm{SO}_{4}{ }^{2-}$ in the field and laboratory (Herron and Langway 1985, Finkel and Langway 1985, Finkel and others 1986), under clean-room conditions. All pit and shallow-core samples were prepared in a continuous sequence of eight samples per year, as identified by other stable and radioactive isotope-dating methods. The deep ice-core samples were selected and prepared from core intervals spaced over the $2037 \mathrm{~m}$ profile from time units which showed evidence of abrupt or transitory periods in climate change or volcanic disturbances, as defined by stable isotopes (Dansgaard and others 1985), atmospheric gases (Oeschger and others 1985) and dust (Hammer and others 1985).

Approximately 1700 new measurements from the Dye 3 samples are included in this study. Variability in the chemical constituents and their concentration levels is present and meaningful on a short-term and long-term basis. The time units measured represent seasons, years, decades, centuries and longer geological periods. Particular attention is given to two new high- and low-frequency detailed chronological data sets from (!) a continuous $26 \mathrm{~m}$ core profile, representing 3000 years, extending from the Holocene/Wisconsin boundary back into the late Wisconsin and (2) measurements made on 106 samples spaced every $2 \mathrm{~m}$ over the Wisconsin-age ice from 1786 to $2008 \mathrm{~m}$.

\section{REFERENCES}

Dansgaard W, Clausen H B, Gundestrup N S, Johnsen S J, Rygner C 1985 Dating and climatic interpretation of two deep Greenland ice cores. In Langway $\mathrm{C} \mathrm{C} \mathrm{Jr}$, Oeschger $\mathrm{H}$, Dansgaard W (eds) Greenland ice core: geophysics. geochemistry, and the environment. Washington, DC, American Geophysical Union: 71-76 (Geophysical Monograph 33)

Finkel R C, Langway C C Jr 1985 Global and local influences on the chemical composition of snowfall at Dye 3, Greenland: the record between $10 \mathrm{ka} \mathrm{B.P.}$ and 40 ka B.P. Earth and Planetary Science Letters 73(2-4): 196-206

Finkel R C, Langway C C Jr, Clausen H B 1986 Changes in precipitation at Dye 3, Greenland. Journal of Geophysical Research 91(D9): 9849-9855

Hammer C U, Clausen H B, Dansgaard W, Neftel A, Kristinsdottir P, Johnson E 1985 Continuous impurity analysis along the Dye 3 deep core. In Langway $\mathrm{C} \mathrm{C} \mathrm{Jr}$, Oeschger H, Dansgaard $\mathrm{W}$ (eds) Greenland ice core: geophysics, geochemistry, and the environment. Washington, DC, American Geophysical Union: 90-94 (Geophysical Monograph 33)

Herron M M, Langway C C Jr 1985 Chloride, nitrate and sulfate in the Dye 3 and Camp Century, Greenland ice cores. In Langway C C Jr, Oeschger $\mathrm{H}$, Dansgaard W (eds) Greenland ice core: geophysics, geochemistry, and the environment. Washington, DC, American Geophysical Union: 77-84 (Geophysical Monograph 33)

Oeschger H, Stauffer B, Finkel R, Langway C C Jr 1985 Variations of the $\mathrm{CO}_{2}$ concentration of occluded air and of anions and dust in polar ice cores. In Sundquist E T, Broecker W S (eds) The carbon cycle and atmospheric $\mathrm{CO}_{2}$ : natural variations archean to present. Washington, DC, American Geophysical Union (Geophysical Monograph 32) 